University of Rhode Island

DigitalCommons@URI

Open Access Master's Theses

1973

\title{
Moral Autonomy and Radical Evil in the Philosophy of Kant
}

David George Horner

University of Rhode Island

Follow this and additional works at: https://digitalcommons.uri.edu/theses

\section{Recommended Citation}

Horner, David George, "Moral Autonomy and Radical Evil in the Philosophy of Kant" (1973). Open Access Master's Theses. Paper 1548.

https://digitalcommons.uri.edu/theses/1548

This Thesis is brought to you for free and open access by DigitalCommons@URI. It has been accepted for inclusion in Open Access Master's Theses by an authorized administrator of DigitalCommons@URI. For more information, please contact digitalcommons-group@uri.edu. 


\section{B 2799 \\ E 8 \\ $H 67$}

\section{MORAL AUTONOMY ANO RAOICAL EVIL \\ IN THE PHILCSOPHY CF KANT \\ BY \\ DAVID GEOREE HORNER}
A THESIS SUEMITTEO IN PARTIAL FULFILLMENT OF THE REQUIREMENTS FOR THE DEGREE OF MASTER OF ARTS IN PHILOSOPHY

UNIUERSITY OF RHCOE ISLANO 3.973 


\section{THESTS ABSTRACT}

The problem which this thesis proposes to treat is Immanuel Kant's attempt to frame an ethical system ultimately based on the postulate of moral freedom (1.e. moral autonomy), and at the same time to espouse what he describes as the doctrine of "redical innate ev11 in humen nature." While the examination may well have sicnificant implications for moral and religlous theorles beyond the bounderies of Kentien thought, generally these tempting vistas are not explored In the thesis. Indeed, the issue may also have broad repercussions for Kant's phllosophy in general but this too lies beyond the scope of the thesis. The investigation is 11 inted as much as possible to the presentation and enelysis of Kant's speciflc arqument for moral autonomy and radical evil as it is found in his two major othical works Critigug of Practical Reason and The Fundamental Principles of the Mataphysic of Ethies, as well as his rallgious treatise, Religion Ulithin the Limpts of Pisasen Alone. However, the mo jor interprotations of Kant's doctrines of morel outonomy and radical ovil are examined In some ditall since the defintion of these terms is crucial for eny examination of theis rompatibility.

The first seation of the thesis, "Moral Rutonomy" consists of a presentation and analysis of soms of the moro prominent and difforing intarpetations of Kant's notion of moral eutonomy. Prinarily, the soction deals with the views of Hans Veihinger, W. T. Jonss, Join R. Silber, and Lewis White Beck. Both the "frasdom as 
fiction" interprection of Vaihinger and the "freedom as personality fulfiliment" interpatation of Jones are rejected as not accurately representing Kant's oun vieve of moral autanway. The Mraedom as sponterieity" interpretation of Silber is endorsed, but it is also suggested that a full understanding of morel autonomy requires the additional insights of Beck with respect to the distinction between "freedom as spontanelty" and "freedom as autonomy." The interpretetion of moral eutonomy upon which the balance of the thesis is constructed 1s, therefore, a combination of the views of Silber and Beck.

The second section of the thesis, "Redicel Evil," contains a systematic presentation of Kant's doctrine of "radical innate evil in human nature." There is much less controversy concerning the dofinition of this term than surrounds the definition of "moral eutonomy." This is probably due to the fact that the only place where Kant fully treass this doctrine is in the Religion and his discussion of it there is thorough and reasonably straightforward.

The final section is an analysis of the compatibility of these two Kantian doctrines. First, it is argued that Kant was very well awa of the danger of contradicting his fundamental ethicel postulate of moral eutonomy in affirming the doctrine of radical evil. Second, due to his cognizance of this danger, he carefully and successfully definud radicel ovil in such a way that it does not contradict moral autonomy. Third, the competibility of these two doctrines in Kant's philosophy may not ultimately be a sotisfactory resolution of the genoral problem of affirming that man is both morally rssponsible and morally depreved because Kont.'s understending of radicel evil is dublous. 


\section{RCKNOULEDGMENTS}

Wh1le the 119t of those who have contributed to and encouraged this study is far too long to include here, a perticulerly great debt of gratitude is owed to the following? To Father Hilliam Paul Has In whose seminer my interest in this problem wes inltially kindleds to Dr. Doneld Zeyl who, as the chairman of the thesis comittee, provided constant ancouragement and onlightenment both in the reserrch and the writing of the thesis; to the other members of the thesis committee, Dr. Fritz Wenisch and Dr. Stanford Cashollars to Dr. Carlton Cregory of Barrington College, for endless hours of Prufteul discussion of the issues and finally, to my wife, for her enduring support and vital assistance in the typing of the thesis. 
TAELE OF CONTENTS

\section{Pege}

INTRODUCTION .................. 1

I. mORAL autOKOMY .............. 3

II. RADICAL EVIL............... 23

III. THE ISSUE OF RECONCILIATION. . . . . 32

SELECTED BIBLIOCRADHY. . . . . . . . . 45 


\section{INTROOUCTION}

The long evolution of philosophical thought has been influenced and shaped by a multiplicity of creative minds. Among this multiplicity, however, a few philosophers en joy a place of particular prominence owing to thelr overtly significant contributions to the development of philosophical inquiry. Immanuel kant occupies such a position. His philosophy, along with that of plato and Aristotle, stands among the most influential both in clarifying perennial philosophical problems and providing direction for future philosophical investigation. This thesis will concern itself with one aspect of Kant's rich philosophy, namely his attempt to construct an ethical system ultimately based on the postulate of morel autonomy, and at the same time to affirm - doctrine of "radical innate evil in humen nature." The issue of man's moral freedom has been a toplc of enduring debate among both philosophers and theologians, and its complexity has been compounded In the case of those who would wish to affirm not only that man is morally frea but also that he is innetely morally carrupt. Many scholars have rather lightly dismissed this latiar position as being obviously contradictory, and yet such a dismissel becomes more difficult when a philosopher of the stature of Immanual Kant is the proponent. The purpose of this thesis, is, therefore, to examine Kant's case for the compatibility of moral autonomy and radical evil. With respect to Kant's writings, the examination will be drawn primarily from his two major ethical works, The fundariental Principles of the Metaphysic of Ethics and the Eritique of Prectical Regson, as 
acll es from Kant's Ieliglous treatise, Religlon Within the Limits of Reason Alone. The first section of the thesis will assess gome of the more significent interpretations of Kant's understanding of moral autonony. The second section will syeteniatically present Kent's dostrine of radical evil as Kant, himself, articulated it in the Religion. Then, given the definition of these two terms the final section wil attempt to evaluate their compatibility.

Although Kant ished to maintain a distinction between ethics and religion, his also recognized their interrelatedness. His comments concerning radical evil in the Religion, therefore, provide a helpful lucidation of the strictly ethical considerations which he undertook In the Metaphysic of Ethics and the Critique of Practical Reason. In much the seme way, then, although the purpose of this thesis is to prasent a treatment of one spseific issua (1.e. the compatibility of Kantian radical evil and moral autonomy) it is hoped that in this process, other concerns both within Kant's philosophy and beyond it wil be highlighted. The consideration of these other 1seves, however, 11 es beyond the scope of this work, and therefore must be left unattended. Nevertheless, perthaps even tinsse unattended questions, which are Impliclt in the particular issue before us, w11. be geen in a new light and w111 therefore receive the attention due to them on another occasion. 


\section{MORAL AUTONOMY}

As mentioned in the Introduction, the Kentian undarstending of morel autonomy mat be explicatad prior to the treatment of the specific problem with which this thesis is concerned (1.0. the apparent contradiction in Kant's concurrently affirming tha notions of moral freedom and innate, redical evil). However, the issue of how Kant understood the term "morel autonomy" must itself be viewed within the context of Kant's discussion of enother apparent contradiction: namely, the contradiction between mozal freedom and natural law. Kant presumably held both "(I) that 'every action that takes place at a certein point of time is a necessary result of what axisted in time preceding,' and so is completely conditioned in accordance with the general principle of causality, and (11) that we are bound to do only what wo ara free to do." ${ }^{1}$ In working towards a Kantian dofinition of moral froedom, therafore, we must keep bofore us the fact that kant sought to define this freedom in such a way that it did not centradict natural necessity and man "s place as a "ghenomenon" within the natural order nor man's dignity 89 a moral agent. The task of this saction is not to critically essegs Kant's cefinition of moral autonomy. Rather, we shall attempt to discover and explain Kant's definition as 1 t is presented primarliy in the Fundemental Principles of the Metephysic of Ethics and the Eritique of Practical

W111iam Thamas Jones, Merality and Freedom in the Bhilosophy of Immenuel Kant: (Oxford University Press, 194n), p. I. 
Reason. In order to do this, it is necessary to consider several

significant interpretations of Kant's use of ths term 'moral autonomy'

before one of these interpretations can be endersed or a new one

given. The three major interpretations which we shall consider are

(1) Hans Vaihinger"s theory of "moral freedom as fiction," 2 (2) W. T. Jones' theory of "moral freedom as personelity fulfillment, ${ }^{3}$ (3) John

R. Silber's theory of "morel freedom as spontaneity."4

In The Philasophy of 'As If' Hans Vaihinger presents his argument on behalf of the "freedom as fiction" interpretation. He begins by quoting from Kant's The Fundamental Princioles of the Mistaphysic of

\section{Ethics:}

Now I say: Everything that cannot act ctherwise than "under the idea of freedom" is therefore in practical respects really free, that is to say, for him all the laws count which are ingeparably connected with freedom, sa if his will were of itself declared to be free and indeed by - proof acceptable in theoreticel philoscphy.

Now I meintein that to each boing who has a will we nust necessaily also attribute the idea of freedom by which alone he sets. For in such a being we cancelve a reason that is procticel, that has causality in reference to its objects. It is impossible to conceive a reeson that in full consclcusness would be directed in respect to its judgments by scme outside source, for then the subject would ascribe the determination of his judgment not to reason, but to some impulsion. Reason must look upon itself as the originator of its principles, independent of foreign influences. Censequently it must, as prectical reason or wil of a rational being. concelve itself as fres, that is to sey, its will can bs will of its own only under the

'Hans Vaihinger, The Ph1losophy of 'As If', tranis. by C. K. Ogden (Now York: Harcourt, Brace, Co., Inc., 1924).

3w. T. Jones, Morality and Freedom.

4 John R. Silber, "The Ethical Significance of Kent's Religion," in the Intro. to Inwanual Kant, Religion Within the Limits of Reason Alone, trans. by Theodore M. Greeng and Hoyt H. Hudson (Nex York: Harper \& Row publishers, 1960). 
1dee of freadan, and this 1dea wust therafore in every practical respect be attributed to 11 rational beings. 5

Vaihinger takes this passage es elear statement of kant's -fictional view" of moral freedon for he (Vaihinger) writes ". . here kant clearly and unemblgiously declares freedom to be but a mere Idea without reality." It must not be essumed, however, that Vaininger thought he was pointing out a deficiency in Kant's morel philosophy. Nor dces Vaihinger suggegt that Kant was unaware of this Interpretation. Indeed, Vaihinger apperently bolleved not only that Kant consefously espoused this view of freedom as fiction but also that Kant saw it as an acceptable resolution of the apparent contradiction between netural law ond moral autonomy. Vaininger insists "Here we reach the highest pinnacle attained by Kantian thought, or indeed, by any human thought. Only a few, only an elite, can continue to breathe at all at this altitude: the vast majority need a different, - less rarafied atmosphere."?

A closer inspection of the passege which velininger quotes, however, falls to lend strong support to elther of Vaihinger's conclusions. First, it is not clear that kant is stating or even implying that moral freedom is ultimately fictitious. Kont simply says,

- Everything that cannot act oth erwise than

"under the ides of freedom" is therefore in practical respects really free...

Reason must look upon itself as the originator of its principles, independent of foreign influences. Consequently

5 Immenuel kant, The Fundamental princigles of the Metaphysic of Ethics, trans, by Otto Manthey-Zorn (Now York: Appleton-CenturyCrafts, Inc., 1938), p. 67 .

6valinings, As If, P. 289.

7 Ibid., p. 293 . 
It must, as pryctical reasori oipalll of a rational being, concelve Itself as free....

In other words, man es a rational being mugt view himself as free (1.e. act "under the 1dee of freedom") and therefore is practically Pree. But this does not necessarily mean thet man is not actually free both practlcally and theoretically. Rather, it simply states that even if man were not theorgtically fres (1.a. ultimately freo) he would still be morally responsible,". - for him all the laws count which are Insepargily connectad wth freedom." 9 Thergfore, kant is wiling to farego the question of man's theoretical freedom on the grounds that its resolution is not essential to the task before him. Indeed, he explicitly states this in note to the very passage which Valhinger quates.

I am edopting this method of assuming as sufficient for our purpose that freedon is merely "as an idea" made the basis of actions of raticnal beings, so that I may be relleved of the necessity of proving freedom in its theoreticel respect alsa. For even when the latter 13 left undone, then for the being who cannot act otherwise then under the ides of his own fresdom the samp laws still apply which would bind en actually free being.

Thus Kant was nct suggesting that morel freedion is a fiction, but only that moral rasparsibility does not require the thaoretical proof of freedom. Indeed, other passeges, both in the Metephysic of Ethics and the Exitigue of Practical Reeson make it clsar that Kant did not consider freedom to bo fictitious. Kant states:

- . It is an indispensable task of speculative philosophy to point out that the deception regarding this contradiction (between netural necessity and freedom) rests upan the fact that when we call a man free wo think of

Bant, Metaghysic of Ethics, $p .67$.

Ibid.

10 Ibid. 
him In anothez sarse and in a diffezent rolation then when we consider him es part of neturs ard subjest to 1ts laws. It must point out also that the two not only can go together very well, but must be regaruad as necessarjly unitad in the same subjact.... 1 .

And in the Celtigue of Practical neason, "Speculative ree in does not herewith grow in insight but only in respect to the certitude of its problematic cuneept of freedom, to which objective, though only practical, reality is now indubitably given." 12 It is certainly true that for Kant moral freedom has a different epistemological status than the concept of nature (1.e. natural law) which "proves and necessarily must prove its reality in examples of experience." 13 Howarer, this is not to say that freedom is a fiction but only that its significance is primerily practical rather than speculative. For Vaihinger's interpretation to stand, it would have to bo demonstrated thet kant equated the objective and the practical with the fictional, and to my knowledgs no such equation is aver made in Kant's writings. Indeed, such an equation saems to be antithetical to the whole thrust of Kent's ethics. As W. T. Jones phrases it:

$$
\text { - - to call a bellef a fletion is to say that }
$$

what is belleved is not the casa. . Kant's whole inquiry was designed to explain the possibility of freedom and theraby to establish that obligation is an objective fact and not an illusion; and it is impossibie to believes that kant could have accepted as satisfactory the conclusion that it (freedom) is a falso hypothesis to which nothing corresponds in fact. 14

${ }^{11}$ Ibld., P. 76.

${ }^{12}$ Immanuel Kant, Critique of Practical Reason, trans. by Lewis thite Beck (New York: The Bobos-Merrill Co., Inc., 1956), p. 50.

13 Kant, Metaphysic of Ethics, p. 76.

14w. T. Jones, merglity and Freedom pp. 44-45. 
It would saem, then, that neither the "latter" nor the "spirit" of Kant's witings tend to support Valinger's conclusion that Kant saw moral freedom as a useful fiction. It may be that such a viaw would resolve the contradiction between naturel las and freedam. But, it would do 80 on tarms unacceptable to kant bacause it would forfelt the moral dignity of man by reducing moral abligation to an 1llusion. W. T. Jones suggests another interpretation of Kant's view of aorel freedom in his book Morality and Fraedom In the philoscphy of Imenuel Kent. 15 Jones' entire discussion of moral freedom pivots around the problem elready referred to of understanding freedom in ouch: way that it satisfies the following criterlas "(1) compatibility wth the principle of causality as laid down in The Criticue of Pura Reason, and (ii) compatibllity with the reality of morality and of obligation." 16 Furthermare, Jones openly afmits that the "Kantien" $\forall$ few of morel freedom for which he argues is not "Kantian" in the sense that it is the only interpretation which Kant explisitly affirmed, but only in the sense:

(1) that this "critical" theory was in fact held by Kent (together, however, with other theories from which he seams never to have distinguished it): (ii) that it satisfles Kant's own "Drablemstellung," while these ather theories do not; (111) that it goes a long way towards being en adequate solution to our own conception of the problem.17

Jones begins his articulation of Kant's "critical" theory by a discussion of the "noumena/phenomena" distinction. Jones rejects the notion thet noumena can be causally efficaclous in the phenomenel world on the grounds that this would contradict netural necessity and

15

Ibid., p. 3 .

16 Inld.

17 Ib1d., 
thereby preserve the reality of moxil abligation at the unacceptable cost of denying the principle of caugality. ${ }^{1.5}$ Jones willingly admits

that at times Kant himsalf thought that noumbnal caussifty was the key to en acceptable resolution of the antinony between freedom and naturel law. However, Jones insists that this view fails to satisfy olther of his firial two criterias the satisfaction of Kant's own "Problemstellung" or the solution to our present vlew of the problem. The best way to present Jones' argument is to quote it,

Let us suppose, In eccordance with Kant's thesis, thet $a, b$, and $c$ are the entecedent events which condition the occurrence of a certain act $p$. Now if on certain occasion, after the occurrence of $a, b, c$, the agant does $a$, what wo ssume, and what Kant himsolf assumes, is simply that some factor $x$ has also occurred, that $x$ is another event, at the moment unknown, and that $a, b, c, x$, conditions the occurrence of $a$. If wa did not make this essumption, it would obviously be in principle impossible to pradict human conduct with certainty, and we should have to abandon the thesis, on which kant insists, that all events happen in accordance with unchangeable iaws.

It is clear, moreover, not only that this assumption leaves no place for the hypothesis that there hes been a mentfestation of noumenal causality, but that the hypothssis itself is really meaningless. For, if $q$ is noumenally caused, then $x$, the factor in the situation which brings it about that $q$ rather than $p$ occurs, is non-temporal. Therefore, though $q$ is an event and occurs, there is no time at which $x$ happens. But whether a happens or not is supposed to depend on whether or not $x$ exerts its efficacious power, and this is really meaningless. It is quite impossible to attach any significance to the idea of $x$ and $q$ varying concomitantly whera $x$ does not "arise or begin at a certain time."

- Hence, on Kant's own torms, thers seems but one conclusion to dras: that noumene are not causally efficacious with respect to phenomene.

After rejecting the causel afficacy of noumena, Jories goes on to develop his intarpretation of morel autonomy by considering the "w111" not as a "spontaneous sxercise of noumanal causality" but as

${ }^{18}$ Ibid., p. 4 and following.

19 Io1d., pp. 7-8. 
- causal, phencmenel, psychicel svent. The peychical amphesizes the w111. cognitive power. The ceval aspect extends the definiton of w11 beyond the merely cognitivs. "practical reason. . does not merely contemplare its objects as non-existent; 1 t contemplates then as objects which we propose to do something about." 20 finally, w111 is phenomenal, which means that it is governed by and sub ject to the laws of nature. Jones is confident that auch an understanding of the w111 is consistent with the demends of natural necessity, and he therefore proceeds to discuss the adequacy of this interpretation wthin the context of morel obligetion.

Jones begins by noting that however loosely one interprets Kant's ethics, it is at least certain that any ethical system which claims to be "Karitian" must contein the concept of the "a priori" charecter of the moral law (1.e. that the moral law is both a universal and necessary and for all men). Jones suggests that there is only one legitimately moral and which fully satisfies this criterions personality, itsolf. "Our account of a morally good act of will is now complate. What distinguishes such an act, as regards its contant, is that it is the kind of act by which personality is realized." 21 The ethical command towards the fulflllment of human personality is universal becsuse reason, as the distinctive part of human personality, is possessed by all men, and it is necessary in the sense of "felt" necessity, bereyse of the peculiar worth of reason. 22

Thus, it is not from the concept of a rational being that we should try to deduce the moral law, but

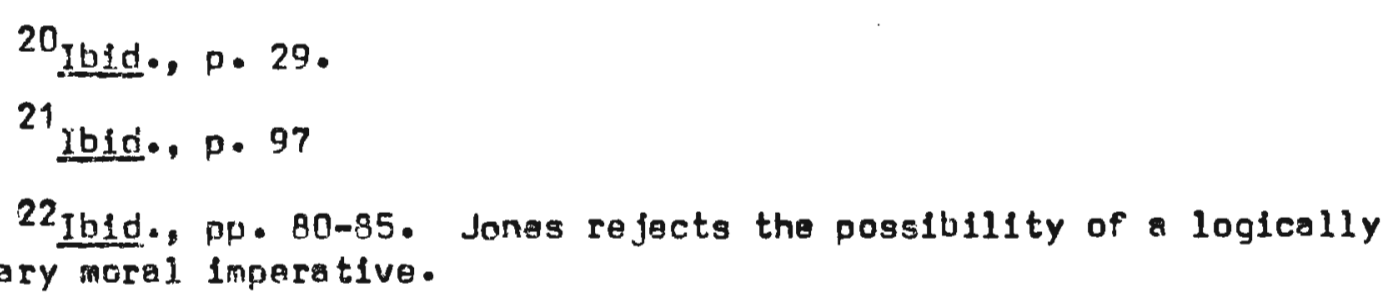
nosessary moral imperative. 
upon the value (or worth) of such a creature that wa should reflect if we would understend both the categorical form and the a plorl end, which are the distinguishing characieristics of the merally good act of w11.23

With this definition of the morel imperative as the categorical and a priorf command towards the fulfillment and realization of personality, and with the concept of w111 as a phenomenel, psychical event, Jones is able to construct "critical" theory of freedon. This critical theory 18, according to Jones, not only a satisfactory resolution of the contradiction between natural necessity and moral freedom on grounds which eliminates neither, but is also "Kantian" in the sense that the theory can be found in Kant's writings in at leest embryonic form. The key question for Jones is, "Does Kant ever give an account of freedom which consists in saying that to be free means to be moved by the kind of thought which we have just described? 24

This thought contains in the first place, the representation of a certain change in the state of affeirs as being one by means of which personality can be realized, and, In the second place, the recognition that the worth of personality has as an and in itself a sufficient ground for producing the change. 25

Jonas believed that he found such an account of freedom in Kent's discussion of the eutonomy of the will. This aspect of the wil which relates to its "self-legislating" furction is certainly central to Kant's ethics, and Jones understands Kant to mean by it, that the will is not only the means by which the moral end is realized but is also the moral and itself. In order to realize this end, it is not necessery, sccording to Jones, that the w11l be frea in the

\footnotetext{
23 Ibid., p. 100.

24 Ibid., p. 101.

${ }^{25}$ Ibid.
} 
sense that it is cepeble of inftlating acts while at the seme time being unaffected itself by previous svents in time (1.0. It is not necessery thet the w11 be "spontaneous"). Rather,

To call an act free is not, in a word, to deny that it is an act, for then, indeed, "a free will would be an absurdity." It is simply a way of characterizing an important kind of practical thought which sometimes moves us. Practical thoughts are, by definition, causes which are, without exception, the effects of antecedent events in time. What distinguishes those which we call free is not, tharefore, the way in which they are causes or effects; but the kind of thought that they are.26

Hence, "freedom - . Is not incompatible with material necessity, because freedom does not mean 'not-determined.'n27 At the same time, freedom understood in this way confirms the legitimacy of moral obligation which is both categorical and a pricri. Dn this basis, then, Jones concludes that a successful resolution of the contradiction between natural necessity and morel freedom is, indeed, possible while st1ll remalning within the general framework of Kant's own philosophy.

Thus there are not two different acts--a noumenal act and a phenomenal act. There is one act (taken as a sequence of events in time), which is througi and through natural, and which differs in no essential way from any other causal serias. But in virtue of being the particular kind of set which it is, a value of a certain distinctive kind is realized. - Moral goodness, in a word, is just that kind of value which 1 s experienceg whenever a certain kind of thought turns practical....

And as it is the concept of freedom which gives expression to this value which reason has in itself, Kant's claim is essentially justified: it is precisely the concepto of freedom which reconciles morality and natural necsssity. 29

26

Ibid., p. 109.

27 Ibld., p. 120.

28 Ibid., p. 137 .

29 Ibjd., p. 139. 
Despite the Initial parstesiverys3 of Jones' argument, it does soem that his position ia susceptible to numerous objections. As stated earlier, Jones admits thet the theory which he develops with respect to freedom is "Kantian" only in a limited sense. Jones proposes that kant held the "freedom as fulfillment of personality" viow, al though he (Kant) espoused other views as well. Sscond, Jones contends that his (Jones') concept of Preedom satisfies Kant's own "problemstellung." We shall not beconcerned with Jones' third assertion, that his interpretetion is a reasonably adequate solution to "our own conception of the problem" between freedom and netural necessity, for this issue lies beyond the scope of our investigation. However, the first and second of Jones' assertions do lie within the bounds of this work and therefore require comment.

Jones begins the development of his own view by rejecting the notion of noumena as being causally efficacious in the realm of phenomena. He states.

- - If $a$ is noumenally caused, then $x$, the factor in the situation which brings it ebout that q rather than $p$ occurs, is non-temporal. Therefore, though $q$ is an event and occurs, there is no time at which $x$ happens. Jut whether $q$ happens or not is supposed to depend on whether or not $x$ exerts its efficacious power, and this is really meaningless. 30

Now, It may be that after a thorough philosophical analysis the Idee of noumsnal causelity is "really meaningless," yet a number of passages suggest thet this (noumenal causality) is precisoly what Kant means. Kant writes in the Critique of Practical Reason:

In the concept of a will, however, the concept of causality is already contained; thus in that of a pure will there is the concept of causality with freedom, i.e. of a causality not determinable according to natural laws and 
censequently not susceptible to eny empisical irituition as proof. - Now the concopt. of a beimg wich hes a

frea will is that of a "ceusa neumenon."

In Rellaion Within the Limits of Reeson Rlorie, Kant states, "To seek the temporal origin of faes acts as such (as though thay were natural effects) is thus a contradiction. ${ }^{32}$

It is clear thet kant not only affirmed the efficacy of noumanal causality but also that he was able to allow for the possibility of events in the phenomenal worid bying the results of noumenal causes which are themselves non-temporal. Nor is this a "maningless" assertion if one is willing to eccept, as kant surely was, that time Is a category of cognition which applies to appearances (1.e. phenomena) but not necessarily to things-in-themselves (1.e. noumena). Kant never suggests that such non-temporal, noumenal causes can be "known," but this by no means excludes the factual possibility of noumenal causality which is all that kant wanted to establish. It simply means that such causes can never be "known" in the strict senss in which kant defined "knowledge." Therefore, it does not seem that Jones' refutation of noumenel causality is cogent on Kantian terms. The quotation from the Critique of Prectical Reason is also evidence, contrary to Jones' view, that the will was not constdered by kant to be merely a phenomenal, psychical process which is subject to all of the natural laws. Kant expressly states that the concept of the will with which he is operating is one of a will which is "not determinable according to natural laws."

31 Kant, Practical Reason, pp. 57-58.

32 Immanuel Kant, Religion Within the Limits of Resson Alone, trans. by Theodore $M$. Greene and Hoyt $H$. Hudson, (New York: Harper \& Row Publishers, 1960), p. 35. 
We must now turn to a considerotion of jones" "critical" theory of fregdom. Agein, it would seem that thls viow is neither true to Kant nor adequate for moral responsibility. While it is true that the notion of autonomy (1.e. self-legislation) is at the core of Kant's ethics, it is not true that heteronomous action for Kant (1.e. action which is not self-legislative and personality fulfilling) is necessarily un-free action. And yet, if we accept Jones' view of freedom, heteronomous action must be un-free. Indeed Jones himself states this:

The assertion of man's freadom is therofore not an ossertion about the way in which cartain events are caused. It is an assertion about a certain kind of value. Herice, we may not say at all that Cain's act of killing Abel was "free," since we can be reasonably certain that it wăs not a sense of duty which moved him to do this act.

But what are we to say of Cain's action? Can he be held morally responsible for an act which is not free? Jones never chellonges the "I ought implies I cank rationale, yet nolther does he ever supply us with an answar as to how we are to consider acts which do not contribute to the fulfiliment of personality and thus cannot be considered fres. Kant had no such protien for he saw both the autonomous and the heteronomous as expressions of a free, morally responsible gent. 34

On tolance, then, Jones' view of freedom as the fulfillment of personality is unsatisfactory because it falls to fulfill even Jones' own criteria. It is neither Kantian in the sense that Kant espoused such a view; nor is it an adequate solution to Kant's "problemstellung" beceuse it erodes the very basis of moral responslbility: the ascription

33 Jones, Morality and Freedom, p. 136.

${ }^{34}$ We shall say more about this in our discussion of 5ilber's view of freedon as spontaneity. 
of moral pralse and olame. It allows us to praise but not to blame by defining Immoral acts as un-froe azts. To call such a view Kantian, would be to fundamentsliy misunderstend the theust of Kent's entire ethical endeevor.

The final viex of moral freedom which we must now inspect is the "freedom as spontaneity" view presented by John R. Sllber in his essay "The Ethical Significance of Kant's Religion."35 In opposition to Jories' strong refutation of spontanoous causation, S11ber explicitiy states, "Responsibility cannot be personel unless it can be concentrated In free individuals who can sct whout being determined to action by external and antecedent couses." 36 And silber takes this not simply as a statement of his own personal conviction, but one which is absolutely consistent with Kant's own view. He cuotes Xant:

What we wh to understand and never shall understand is how predeterminism, according ta which voluntary actions, s events, have their daternining ground in antecedent time (which, with what happened in it, is no longer within our power), can be consistent with freedom, according to which the act as well as its opposite must ba within the poxier of the subject at the moment of its taking place.37

Freedom then for silber and for Kant implies spontaneity (1.8. the Independence of the 111 from external infiuences and ant acedent determination!.

* 3 wotgd earlier, Jones' view of freedom precludes the possibillty : heteronomous action being free action, because heteronomous action folls, by definttion, to be "personality-fulfilling" experience. silber has no such problem. For him, "Heteronomy and outonomy are

\footnotetext{
${ }^{35}$ silber, "Ethical Significance," pp. 1xxix-cxxxiv.

$36_{\text {IbId., p. } 1 \times \times \times v i 1 .}$

37 Kant, Roligion, o. 45 .
} 
the two primary modes of expressing transceridental freedom." 38 Evan If one chooses to act on the besis of his strongest passion or desire, this is done, according to s1lber, on the besls of the freely chosen maxim of choice, which says that "I shall act accosding to my strongest desire." This ect, therefore, is sponteneous (1.8. free), and yet it is not a "fulfilling realization of transcendental freedom." 39 Whilo heteronomous action is as much the actualization of transcendisntal freedom as is eutonomous ection, It denies this freedom in principle by acting as if no such freedon were possible. For example, an animal presumably acts, on the basis of its strongest desire. However, an onimal, according to Silber, is not free. But, it is important to note that the animal is not free not because it acts heteronomously but because it does not have a will which is free from external influences and provious determination. Man, who is frea, may choose to act like an animal (meroly on the basis of his strongest desire); in which case man acts heteronomously. But man, even in acting in this way, nevertheless remeins free because his action is the result of a mexim of choice, whereas the animal's action is not. Heteronany and autonomy, are, therefore, both expressions of man's freadem. The latter confirms man's freodon by practically axhibiting its possibility. The former deniss it by ecting as if freadom were not possiblo.

With this understanding of fregdom es spontaneity, S1lber goes on to explicate Kant's definition of the will. As one might expoct, this definition is radicelly different from Jones' theory of the 111. silber staies thet although Kant construed the will as a "unitary

38

Silber, "Ethical Signfficance," p. Ixxix.

39

Injd. $p \cdot x c$. 
feculty," nevertholess he thought. It heloful for purposes of analysis to distinguish three separate functions of the w111. The first function of the will is denoted by the word, "Willkur": the power to choose between alternatives. In the fulfiliment of this function, the will 18 a faculty of desirs, "for Kant held that Willkur is determined according to the strength of the plessures or displessures it anticipates In connection with the alternatives open to 1 . $^{40}$ However, w111kur must not to understood as a sort of animal instinct, for this would deny the very fresdom which kant was attempting to establish. What WIIlkur does imply is that man's 111 is influenced by impulses and determined by the strangest impulse, but that W111kuI is free in the decision as to which impulse is to be the strongest. Only after this cholce has been made can wa say that man's choice is determined by the strongest impulse. Thus, uf11kur does not dony humen freedom but presupposes it.

Whareas Willkur rafers primarily to ths capacity of the will to choose, Silber suggests "ll118" is introduced by Kant as representing the "purely raticnal aspect of the w11l." 41 willhir is free to choose those maxims which are in accord with the moral law, thereby affirming Its froodom, os to adopt other axims inconsistent with the moral law thereby abnegating its fresdom, but llille constitutes the will's own demand for self-fulfillment. As such, wille implies an incentiva towards selfarealization, internal to the will. It is precisely because llilie is a part of men's will, that moral experience is "autonomous"

$$
\begin{aligned}
& 40 \text { Ibid., p. xcv. } \\
& 41 \text { IbId., p. oiv. }
\end{aligned}
$$


In the sense that the cetegorisal imparatius is a self-imposed demand. The function of $1111 \mathrm{~g}$, then, is to provide en incentive to willkur to adopt these maxims which ore consistent with the noral law. As an Incentive towards the moral law, the desire which w11le arouses In Willkur is described as a "moral feeling" which consists in the "simple respect for the morel law." "The predisposition to personality (y1110) is the cepacity for respect for the moral lay as in itself a sufficient incentive to the will (w11lkur). This capacity for simple respect for the moral law within us would then bo moral feeling. 42 W112e, then, is a sufficient incentive to motivate w111kur to choose maxims in accordance with the moral law, but it is important to notice that wille is only en "incentive." That 1s, Wiliedoes not predetermine WII kur, which is always free to go against wiIle and the dictates of the moral law. Finally, el though wilikur cen choose to ignore the Incentive of Wille and fail to fulfill its own freedom, WJIIkur can never be entirely devoid of Wille for "when the incentives which can spring from freedom are taken away, man is reduced to a merely animal being." 43 Such a reduction would render mcral experience meaningless and 1s, therefore, unthinkable for Kant.

The finel function or faculty of the w1ll which Silber describes is what Kant denotes by the word, "Gesinnung." He (Kont) describes it as "the ultimate subjective ground of the adoption of maxims." 44 Gesinnung is freely chosen by Willkur, and thus every man is morally responsible for his Gesinnung. As the "ultimate subjective ground

\footnotetext{
${ }^{42}$ Kant, Reliqion, pp. 22-23.

43 Ibid., $p \cdot 30$.

44 Ibld., $\beta$. 20.
} 
of the edoption of maxims," Leslnnumg io the underlying maxim which promotes the choice of particular maxims. Thus any given moral act Ia traceable not only to "superficlal" maxim but also to an underlying maxim. In 80 far as we are able to sab beyond the perticular mexims to the level of the Gesinnung, we can perceive not only the morelity of the specific maxim but also of the underlying maxim as woll. In the Metaahysic of Ethics and in the Critique of Proctical Rasan, Kant analyzed man's moral experience almost exclusively in terns of specific or "superficial" maxims. It is only when we come to the Religion and Kant's fullest articulation of his understanding of the will that we see him locating the heart of morality at a deeper level, the level of Gesinnung. This new dimension however, is extremely significant for Kant's concept of radical evil, as wo shall ses later.

This then ie silber's view of moral fregdom. He begins by defining freedom as spontaneity (freadom from external and antecedent causes) and from thero goes on to present thie process by which this freedom is operative through the compound functions of the will. Any critical coments which could be made about Silber's Interpretetion of Kant's view of freedom would inderd be brief, because it would seem that his explicetion of Kent's witings, as far 85 it goes, is fundementally correct. However, Lewis White Beck in his commentary on Kant's Critigue of Practical Reason helpfully expands Silbar"s position, particularly with respect to the interralation of W11lkur and Wilg.

45 Lewis White Beck, A Commentary on Kant's Critique of Practical Regson (Chicago, Illinois: University of Chicego Press, 1960), pp. 176-209. 
Beck distinguishes betwesn tho modes of freedom: spontaneity and autonomy. Freedon in the sense of spontensity refers to the operative functioning of the will as Willkur. Freedom in the sanse of autonomy relates to the exercise of the will as Wi1le. Wille is always freo in thet its decrees follow from its own nature necessarily. This type of freedon Beck calls "'freedom in the positive sense," cr autonomy." 46 The sponteneity of Willkur is "'freedom in the negative sense' or freedom from nature." 47 While wille is always free, w1llkur is not. In the sense of spontanelty (1.8. freedorn from external influences and entecedent determination) Willkur is fres oven in evil actions, but Willkur can be free in a "complete" sense only when spontaneity and autonomy join in a truly moral action. Therefora, heterononous acts are free, and Beck's view does not suffer from the same deficiencies as Jones'. Sut at the same time Beck's view has the virtue of accounting for the "necessity" of the categorical imperative by showing that only In moral acts can full freedom be realized. Thus man can be both morally preised and blamed, and yet the moral law is still the necassary condition of mari's fullest realization of himself. Beck's view, then, does not contradict Silber's but amplifies it. The two, when taken together, accurately represent the views of Kant which he doveloped throughout the Metaghysic of Ethics, Critique of Practical Reason, and the Religion.

Moral freedom for Kant, then, is not a fiction; nor is it defined in such a way that evil acts cennot be attributed to a free and responsible moral agent. Rather, the freedom raquired by morality

\footnotetext{
${ }^{46}$ Ibid., p. 197.

47 Ibid., P. 196.
} 
and consistent with natural recgsgity sees man a a "causa noumenon," whose freedom is spantanaous in ths exarcisa of U111kur and autonomous In the decrees of $11: 12$. Man fully uctuallzes his freedom, however, only when the "obligation-creating" function of Nills is united with the "obligation-executing" function of Willkur. " 48 Thus the categorical imperative is both autonomous to men and necessary for the realization of his fullest humanity. We must now go on to discover how Kant defines Innate, radical evil in order to see if it is consistent with this understanding of maral autonomy.

${ }^{48}$ The terms 'obligation-creating' and 'obligation-oxecuting' are introduced by Beck in A Cummentary, p. 199. 
II. RADICAL EVIĹ

In his essay "The Ethical Significance of Kent's Religion," Silber remarks, "So elosg then, in Kant's thinking is the relation of religion to ethics and so dependent is the former upon the latter, that Kant could scarcely have wirtten a book on raligion without simultaneously illuminating and expanding his ethical theory." 49 This same point was made in our introduction and indeed the vital relationship betwoen Kantien ethics and Kantien religion is basic to the rationale implicit in the purpose and methodology of this thesis. However, we must be careful to understand that ethics and religion for Kent are connected but not identical. Kant, himself, emphasized this in his prefaca to the first edftion of the Rellgion. "So far as morality is based upon the conception of man as a fres agent who, just because he is free, binds himself through his reason to unconditioned laws, It stands in need neither of the idga of another Being over him, for him to apprehend his duty, nor of an incentlve other than the law itself, for hin to do his duty." 50 Therefore, the first thing that ought to be noted about the significence of Kant's religion for Kant's othics is that ethics is not dependent upon religion, and in fact, the reverse is much closer to the case. However, in the Religion and most particularly in the discusalon of "radical evil," Kant expands the ethical and motephysical considerations aiready expressed in the

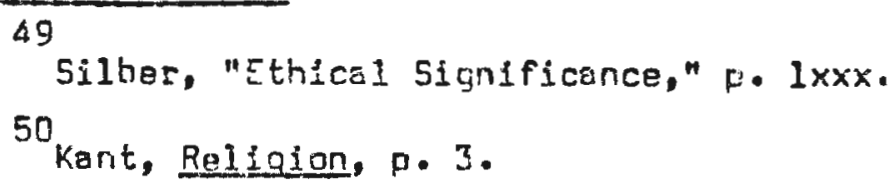


Metaphysic of Ethles and the Critigtie of Psecileni Resson. As

Donald Freeman has put it, Kant's "understanding of human froedom comes to 1 to fullest expressior in his doctrina of radical evil and is further lllumined by his treatment of the bibilcal account of the foll. 51 We must now turn to an examination of Kant's doctrine of redics 1 euil to find whether it 13 indeed the "fullest expression" of Kant"s understanding of human freedom or whether it involves the contradiction of this understanding.

From Kent's arliest commants about redical evil, one thing is clear: we must understand radical evil in such a way as not to deny the reality of moral experience. Mman himself must make or have wade himself into whatever, in a moral sense, whether good or evil, he 18 or is to become. Either condition must be an effect of his free cholce; for otherwise he could not be held respensible for it and could therefore to morally neither good nor evil." 52 Radical evil, therefore, cannot mean thet man possesses a corrupt Willkur. which enablos him to adopt only evil maxims beceuse this would deny the meaning of moral experience. Nor, however, can man be salo to possess a corrupt lifile, for the incentive towards fulfillment of the

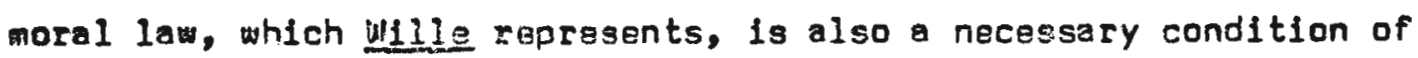
moral freedom. Therefore, since the sourcs of evil, just as the source of good, must 11e within the will, and since we have eliminated Willeus and Wille $3 s$ potential sources of evil, tha source of radical ev1l must be within the Gesinnung. Kant lays the groundwork for

51 Donald Dele Fresmen. Radiral Evil and Original Sin: Kant's Doctrine of Eregcom in Existential ferspective, Doctoral Thesls for Drel Univarsity (Ann Arbor, Michigan: University Microfilms, Inc., 1969), p. 7 . 
locating radical oul in Gesinnung by uzsoussing three "predispositions" implicit in men's natura.

The first predisposition is the "predisposition to animality." This predisposition manffesty itself in man as the desiro for selfo preservation, propagation of the specles, and community with other men (1.8. the social impulse).53 The second is the "predisposition to humanity" which manifests itself as an inclination to compara oneself with other indlyiduals and to judge one's worth and happiness In those terms. 54 That is, the "predisposition to humanity" represents a kind of social consciousness. The third predisposition, is the "fredisposition to personality," which represents "the capacity for respect for the moral law as in itself a sufficlent incentive of the will (Willkur)."n Kant labels all three of these predispositions as original in man in that human nature presupposes all three. That is, a man could not be a man without possessing ell three of these predispositions. These predispositions are not only original in man, but they are also good because they "enjoin the abservance of the law." The first two predispositions (1.e. to animality and to humanity) can lead to vices: for example, gluttony and drunkeness in the case of the predisposftion to aninality and envy in the case of the predisposition to humanity. However, these vices are not described as "rooted" in the predispositions but rather "grafted" upon them. 56 That is, although a vice such as envy can bo traced uitimetely to the desire to compare oneself with others, which is the manifestation of

53

IbId., $p \rho \cdot 21-22$.

54 Itid.

55 Iojd., pp . 22-23.

56 Ibid. 
the predisposition to humenity, ervy is net a necessery result of the prodisposition to humenity. Thus, while human nature presupposes all three predispasitions, the vices wich are treceable to the first two predispositions are not essential to man's nature. Therefore, they are not described as "rooted" in human neture, but rather "grefted" upon it. The predisposition to personality can never lead to evil since it expresses the very essence of moral goodnsss (1.e. respect for the moral law). In the sense that all threa predispositions are inclined towards the good, in that they "en join the observence of the law" and in the case of the third predisposition in that it expresses moral goodness itself, man can be sald to possess an "original predisposition to good." 5 ? In stating that these predispesitions are towards the good, Kant rejects what was then the popular notion that the sinful is to be Idientified with the sensual.

Kant, therefore, along with Kierkegeard, "parries the rationalistic view that the sensul itseif is sinful." - - Sin is not for Kant, as it was for Ritschl, "the contradiction in which man finds himself, as both a part of the world of nature and a spiritual personality claiming to dominate nature." . . Certainly the contrast between man's finitude and his rationality, his sensible needs and inclinations and his unconditional moral destination, is of great significence far Kant's view of mand his condition. But this contrast itself does not make men an fvil, a sinful being. Here agein, Kant repudiates the stolcal rationalism with which he is usually charged. The valient stoics, he said, were mistaken in seeing evil only in "undisciplined natural inclinations," where in fact evil is really "an invisible foe who screens himself behind 58 reason and is therefore all the more dangerous." ...

Nevortheless man can choose to ignore the dictates of these predispositions and turn himself towerds evil rather than good. And it is

57 Ibid., $\mathrm{PP} \cdot 22-23$.

58 1 ilen W.. Wood, Kant's Morai Religion (Ithaca, New York: Cornell University Press, 1970), p. 210 . 
here that we begin to see the unfoloing of kant's undarstanding of redicel evil.

For Kant, man 18 confronted by choice between two kinds of good both of which are related to the three predispositions inherent In every human being. All three predispositions are good, but man Is seid to be evil when and if he reverses the priority of these goods. That is, a man is evil if he adopts maxims which subordinete the incentive of the moral law to the incentive of the "natural" Impulses ( 1.8 . the predispositions towards animality and humanity): Conversely, a man is good if he recognizes the priority of the moral law and chooses maxims which subordinete the "natural" impulses to 1t. Once again we need to emphasize that the basic morality of an individual is located at the level of Lesinnung. Therefore, the subordination of the naturel impulses to the morel law or the reverse takes place at this level. man whose Gesinnung is oriented towards the adoption of maxims which affirm the priority of the moral low is good, and a man whose Eesinnung is oriented towards adoption of maxims which subordinate the moral law to the natural impulses is evil. For Kant, there is no neutral ground; one is either good or avil. One either recognizes and affirms the priority of the moral law and is good or subordinates this law to othar incentives and is ovi1. 59

Thus, we understand the meaning of the term 'evil' for Kant. A man is said to be "eviI" when he subordinates the incentives of the moral law to tha incentives of his natural impulses at the level of Eesinnung. 
We cell a man evil, howsuer, not beceuse he performs actions that are evil (cantrary to lisu) but beceuse these actions ara of such a reture that wa may Infer from them the presence in him of ev1l maxirs.... In order, then, to call a man ovil, it would hays to be possible "a prior1" to infer from several evil acts done wth consciousness of their ovil, or from one such act, on underlying evil maxim; and further, from this naxim to infer the presence in the agent of an underlying common grand, Itself a maxim, of all particular morally-ev 11 $\max 1 m s .60$

But Kant wished to de more than define 'evil,' he aiso wanted to demonstrate that this evil is "natural" in man, cancept which is expressed by the phrase "propensity to evil. "61 a "propensity" is distinguished from a "predisposition" In that a propensity is acquired, wherees a predisposition is "given." 62 Again, this propensity to evil is located in man's Gesinnung. Although moral evil ralates to Willkur in that a man becomes morally good or evil only through the exercise of his ective will (1.0. Willkur), this activity is manifestad in the orientation of Gesinnung. Man's uropensity to evil 18, therefore, acquired but at the same time kant deseribes it as "natural" or in men "by nature." To some, the assertions that man acquires his propensity to evil and that this propensity is in man "by nature," would seem to be blatantly contradletory. But, Kant defines nature in such a way as to incorporate within it the exercise of freadom rather then excluding it.

Lest difficulty at once be encountered in the expression "nature," which, if it means (as it asually does) the opposite of "freedom" as a basis of action, would fiatly contradict the predicates "morally" good or ov11, let it be noted that by "nature of man" wa here intend only the subjective ground of the exercise (under objective

Ibid., $p .16$.

61 Ibid., $p \cdot 23$.

62 Ibid., $p .24$. 
moral laws) of man's freadom an genewhl, this ground-whatever is its character- is the nacessary antecadent of every act apparent to tha senees. But this subjective ground, sgain, must itself always te an expression of freedom (for otherwise the uge as buse of nien" 3 power of choice in respect of the moral law could not be imputgd to him nor could the good cr bad in him be called moral). 63

This means that the propensity to evil can be cansidered as "belonging universally to mankind"64 or "can be predicated of man as a species, 65 although not in the sense "that such a quality cen be inferred from the concept of his species (that 18, or man in general)--for then It would be necessary; but rather that from what we know of man through experience we cennot judge otherwise of $h i n$, or that we may presuppose evil to be subjectively necessary to every man, even to the best." 66 Kant sometimes refers to this propensity as "innate," but this is not to be understood as denying the fact that man acquires his evil disposition.

We shall say, thereforg, of the character (oood or evil) distinguishing man from other possible rational beings, that it is "innate" in him. Yet in doing so we shall ever take the position that nature is not to baar the blame (if it is ovil) or take the credit (if it is good), but that man himself is its author. But since the ultimate ground of the adoption of our maxims, which must itself lie in free choice, cannot be a fact revealed in experience, i.t follows that the good or evil in men (es the ultimete subjective ground of the adaption of this or that maxim with sefarence to the marai iaw) is termed Innate only in this sense, that it is posited as the ground antecedent to every use of freedom in expexience. . .

63 Ibid., pp. $15-17$.

64 Ibid., p. 25.

65 Ib1d., p. 27.

66 Ibid.

67 Ibid., p. 17. 
Finally, the ovil dispogition is termed aradical" precisely because men must besr the responsibility for its presance in him. mence we can call this a netural propensity to evil, and as we must, after all, ever hold man himself responsiblo for it, we can further call it a 'radical' Innata 'ev11' in human nature (yet none the less brought upon us by ourselves)." 68

Finally, we must comment on the possibility of a "restoretion... of the original predisposition to good." 69 Thus far we have established that man possesses a propensity towerds evil which corrupts his Gesinnung. However, since man is commanded to attain the "good," It must be possible for him to do so,". . duty bidis us do this (i.e. become good), and duty demands nothing of us which we cannot do.n ${ }^{70}$ Therefore, there must be some way for men to reorlent his Cesinnung and become morally good by adopting maxims which offirm the priority of the morel law. Kant confesses that this is a problem which is not easily solved. "How it is possible for a naturally evil men to make himself a good man wholly surpasses our comprehenston for how can a bad tree bring forth good eruit?" 71 Although ne obviously did not feel confident that he had an entirely satisfactory explanotion for man's moral regeneration, Kant did suggest that it must be understood as a "revolution" or "rebirth." 72 That 1s, man's Geginnung must be

68 Ib1d., p. 28.

69

Ibid., p. 40.

$70_{\text {Ibid., }}$. 43 .

71 Ibld.: p. 40 .

72

Ibid., p. 43. 
reversed from its orientation toweres ine suvordination of the morel law to a new persoectiva which recognizes the priority of this 1aw. Kant viaws this revolution as being effectud by the individual although ence aga in he admits his fallure to fully comprehend the

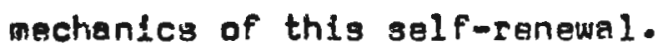

This, then, is Kant's explanetion of "radlcal innate evil in humen nature." Evil is freely chosen by man. Nevartheless, this ovil is universal and thus can be predicated of all men. Through Willkur men frealy chooses to orient his Gesinnung towards the adoption of maxims which subordinate the moral law to naturel incentives. Thereby, man's will becomes morally evil. This ovil, though "In human nature," 1s attributable to man's free cholce and is, therefore, morel oull. Despite the possession of this "radical ovil" man is commanded to follow the "categorical imperativa" by reorienting his Gesinnung. This can only be accomplished through a personal "rebirth." 
III. THE ISSUE OF RECONCILIATION

As stated earlier, Kant held that we are obligated to do only what we are able to do. Thus, the reality of moral experience demands that man is a fres and responsible agent,

- - the moral principle itself serves as a principle of the deduction of an inscrutable faculty which no experience can prove... This is the faculty of freadom, which the moral law, - - shows to be not only possible but actual . . - The moral law is, in fact, a law of causality through froedom and thus a law of a supersensuaus nature. 73

In the first section of the thesis, a definition was suggested of this problematical concept of freadom. It was concluded that for man to be genuinely free, in the Kantien sense, his will must be viewed as a "causa noumenon," capeble of initiating events in the "phenomenal" world, whlle at the same time immune from determination by external influences and antecedent occurrences (1.8. the w11l of man must be spontaneous). Additionally, the cetegorical and "a priori" status of the moral law requires that man's "fullegt" freedom be defined not merely as the spontaneous exercise of M11lkur but also as the autonomous dictates of wille. That 1s, man realizes his "fullest" freedom and humenity when Willkus spontaneously chooses the autonomous incentive of wille and fulfills the categorical imperative by adopting maxims which are consistent with that imporative + t of pure respect for the moral law.

In the second section of the thesis we articulated another significant Kantian notion, "radical innate evil in human nature."

${ }^{73}$ Kant, Critique of Practical Reason, pp. 48-49. 
Here Kent eppeared to portray the univergal condition of man as being one of pervagive moral corruption. Thet is, ell men have chosen to subjugate the dicteres of the moral law to the denands of the "natural" 1mpulses. By Insisting that this is a universal, Innate and inextirpable condition of wan, Kant has been accused by some of falling into a contradiction which is similar to the antinony between natural law and freedom. It is charged that Kant defines man's moral condition in such a way that he (1.0. man) is morelly determined, and this is, Indeed, as great a problem for Kantian ethics as is the 1ssur of man's determination within the realn of nature. The task of this final section 1s, therefore, to consides carefully the implications of both Kant's definition of freedom and his definition of radical ovil in order to discover whether thay ara, in fact, irraconcilable, or whether Freeman is correct in his belief thet "Kant's understanding of human freadom comes to its fullest expression in his doctrine of radical ov $11 \cdot{ }^{74}$

One place in Kant's discussion of radical evil at which it might seem that kant is committed to a view of man which denies moral autonomy, is in his treatment of man's "sensuous nature." 75 It has been suggested that because the "sensuous nature" motivates man to adopt other incentives into his maxim than the moral law, it must be considered as a predisposition towards evil since the moral law requires that it (i.e. the morel law) be odopted as the "sole incentive." Moreover, since Kant defines the "sensuous nature" as a given part of man's personality, this mature must be considered as an orlentation towards

\footnotetext{
74Donald Freeman, Radical Evil, p. 7. 75 Kant, Religion, pp. 21-23.
} 
ovil fo which man is not responsible. Thareforg, man is detarmined

to bo evil in that on sssential part of his personelity 1s, by definition, oriented towards avil. ?5

However, upon a closer inspection of the text, it becomes clear thet Kant's definition of man's sensuous nature does not in fact comit him to this position of moral determinism (or perhaps more correctly, moral predeterminism). The ovil in man is not the result of his adopting maxims which include the incentives of the sensuous nature. Rather, it is the result of man's choosing to giv a the moral

law a lower priority than the natural incentives.

Hence the distinction between a good man and ane who is evil cannot 118 in the oifference between the incentives which they adopt into their maxim (not in the content of the maxim), but rather must depend upon subordination (the form of the maxim), 1.e. which of the two incentives he makes the condition of the other. Consequently man (even the best is eyil only in that he reverses the maral order of the incentives when he adopts them into his maxim. He adopts, indeed, the moral law along with the law of self-love; yet when he becomes avare that they cannot remain in a par with each other but that one must be subordinated to the other as its supreme condition, he makes the incentive of selflove and 1ts inclinstions the condition of coedlence to the moral law; whereas, on the contrary, the latter, as the supreme condition of the satisfaction of the former, ought to heve been adoptad into the universal maxim of the will as the sole incentive.7?

It would seem, then, that silber is right in his conclusion that, "Many moralists and theologians have sought the condition or occasion of avil in man's sensible natura. Kant, however, explicitly rejects this position and argues that man's sensible nature, neither ovil in itself nor the occesion of evil, is good and worthy of fulfillment." 78

76

This opinion was advanced by the euthor of this thasis in an eariler paper on this topic.

${ }^{77}$ Kant, Reliqion, pp. 31-32.

${ }^{78}$ Sizber, "Ethicai Significance," $p \cdot \operatorname{cxil.}$ 
Thus, If man's sansuous nature does rot ccntradict moral freadom, any contradiction between kant's doctrinas of radicel evil snd moral autonomy must be found elsawery. However, the search for such a contradlction ultimately proves fruitless, beceose Kant wes very well aware of the denger of contradicting hinself and skillfully avoided it. This 1 s not to say that Kant's concept of radical evil or his concept of moral eutonomy is thoroughly satisfactory (wo shall have more to say about this later), but it is to say that kant defines these two terms, and particularly "radical ovil," in such a way as to systematically avoid any contrediction of freedom. At every crucial polnt where kant comes close to defining radical evil such that a contradiction with moral autonomy would be generated, he demonstrates clear understanding of this threat. At first glance, the introduction of the term "radical innate evil in human nature" seems to present genuine difficultios for moral froedom, but after Kant's defintion of this term is understood, the difficulties are rasolved. For instance, we generally consider something which is "innate" as something which is "given." Indeed, Kant defines man's evil as "innata" in the sense that this evil "Is posited as the ground antecedent to every use of freedom in experience." 79 But he gives this definition only after clearly stating that the evil in man is attributable to "man himself" as its "author." 80 Therefore, man's evil is not "innate" in the "given" sense, hut only in some spocial sense which Kant, himself, defines. And this definition precludes the possibility that "innate" evil in man can contradict man's moral freodom, because Kant makes this

$$
\begin{aligned}
& 79 \text { Kant, Religion, p. } 17 . \\
& 80_{\text {Ibid. }}
\end{aligned}
$$


Innate ovil in man the rosult of man's freodon (i.s. man is the author of it). Now, it is not clear how man is responsible for this evil, if the evil is "antecedent to avery use of fresdom in experience." Kant attempts to resolve this problem by stating that it is a - . contradiction to seek the temporal origin of man's moral character, so far is is considered as contingent, since this charecter signifies the ground of the exercise of freedom; this ground (11ke the determining ground of the free will generelly) must be sought in purely rational representations." 81 Therefore, Kant believed that man could be held responsible for the evil in $\mathrm{him}$, while at the same time this evil could be described as "antecedent to every use of freedom in experience." While the adequacy of this explanation may be doubtful, nevertheless, the cruciel point is that Kant defines 'innatg' in such a way that it does not violate the concept of morel freedom by being beyond man's control.

The same situation arises with respect to Kant's definition of "human nature." Rather than something "given" to man for which he bears no responsibility, "human nature" for Kent is, "the necessary antecedent of every act apparent to the senses. But this subfective ground, agin, must itself always be an expression of fresdom -. ${ }^{82}$ As ebove, the Kantian reconciliation of these two opparently contradictory assartions that man is morally responsiblo for his "human naturg" and that this nature is "the necessary antecedent of every act apparent to the senses," lies in Kant's insistence that man's moral character does not have a temporal origin. Therefore,

$$
\begin{aligned}
& 81 \text { Ibid., p. } 35 . \\
& { }^{82} \text { Kant, Religlon, p. } 17 .
\end{aligned}
$$


responsibility for "human naturg" can be attributad to man, desplte the fact that this natura is necessarily antecedant to avsry temporal act. Again, the philosophicel efflcacy of Kant's defense might be called into question, but the salient point remains that kant defines 'Innate' and 'humen nature' such that thelr definitiore do not deny the reality of moral autenomy.

We conclude therefore thet Kant's definition of radical evil 1s not in fact contradictory with his notion of moral freodom. But this is net all that nesds to be ald about the problam, for at the same time that kant qualifies his definition of radical ovil in order to avold contradicting moral freedom he attempts to do full justice to his notion of radical evil. Thus kant sought an understanding of radical evil which not only falls to violate moral freedom but also fairly represents what Kant took to be man's universal, sinful condition. Therefore, if any eriticism of kant's two concepts is to be given, it ought to be centered not around the iricompatibility of radical evil and moral freedom but around the adequacy of the former as a meaningful and cogent description of man's stato.

However, before we consider the adequacy of Kont's doctrine of radical suil, we must point out a possible contracistion with another of Kant's metaphysical postulates besides the postulate of human freedom. In the Critiqug of Practical Reason, Kant begins with moral experience and Jerives from it the "Q priori" truth of the moral 18w. From the certainty of the moral law, Kant darives three metaphysical postulates: (1) humen freedom, (2) the immartality of the soul, (3) the existence of God. 83 The argument for the immortality 
of the soul is rather simple. Kent suggests that the ettainment of the highest good is a necessary condition of the moral law. However, the attainment of the highest yond imolies as its necessary condition, the "complete fitness of intantions to the moral law." Since, the attainment of the highest good is a necessary condition of the moral law, the necessary condition (1.e. "the complete fitness of intentions to the moral law") of this necessery condition (1.8. the attainment of the highest good) is also necessery. But, this "complete fitness" implies "holiness" which is unattainable in this 1ife. Therefore, the attainment of "holiness" requires the existance of an "endless progress to that complete fitnss3." In turn, this "endless progress" requires (1) "an infinitely enduring existence" and (2) the "personality of the same rational boing." Taken together, these two characteristics define the immortality of the soul. In short, the lamortality of the savll is proved by shawing thet it stands at the and of a series of necessary conditions ultimately traced back to the "a priorl" existence of the noral law.

However, in the Reliaion and specificaliy in his discussion of Gesinnung, Kant suggests that there is a gap between man's moral disposition and his actions whtch ara carrigd out through his "sensuous nature."

That is, it a man reverses, by a sinnis unchengsable decision, that highest ground of his maxins urereby he was an evil man,. - he is, so far as his principle and cast of mind are conesrned, a subject susceptible of goodness, - . But in the judgment of men, who can eppraise themselves and the strength of their maxims only by the ascendancy which they win over their sensuous natuze in time, this change must be ragarded as ngthing but an everduring struggle toward the better...

${ }^{84}$ Kont, Religion, p. 43. 
The revarsal of men's Gesinnung fron the propensity towards ovil to en orientation towards the good is the key to moral goodness. It is In fact, the essence of moral goodness, for Kant. Howevas, even when this reversel or revolution is effected it somehow falls to menifest Itself In overt actions due to man's sensuous nature. Thus, man 8803 himself es progressing "towerd the better," when in the sight of God, he hes already atteined goodness. 85

However, this calls into question the entire notion of the connection between Gesinnung and action as it relates to moral status. Presumably for Kant, actions are irrelevant to morality because "good" actions can result from evil maxims. Therefore a man's moral status is entirely dependent upon the inclination of his Cesinnung. However, if this is the case one wonders why Kant thinks it necessary for man to possess Immortality in order to attain "holiness." Kant's proof for the immortality of: the soul rests upon the assumption that since holiness is commanded by the moral law, it must be attainable. But, since it is not attaineble in the "world of sensa," the immortality of the soul is necessary to fulfill the moral law. The key to this proof and its apnlication to Gesinnung is the definition of "holiness." Thera are two alternative ways of understanding this term. The first is to make "holiness" synonymous with the concept of " "holy will" which Kant defines as a "will incapable of any maxims which conflict wh the morel law." 86 However, if Kant intended to use "holiness" in this way when appliad to man's moral development, then it would seen that the immortality of the soul is totally irrelevant to the attainment

\section{$85_{\text {Ibid. }}$}

86 Kant, Eritique of Practical Reason, $p .32$. 
of such a state. The attainment of "holiness" is represented as an evolutionary process which requires an infenite amount of time to offact thus, the necessity of the immortality of the soul. But, if "holiness" is understood 95 man's becoming "incapable" of adopting ony waxims which conflict wh the moral law, then whet is necessary is not an infinite amount of time for man's moral evolution but rather - mirsculous event. To make men "holy" in this sense would require - supernatural act which would change the essence of man's personality. At times Kent comes close to suggesting that this is exactly what is necessary, but if this is the case then there is no reason why the Immortality of the soul is essential. The other alternative is, that Kant understands "holiness" as something different from a "holy will" when he describes "hol Iness" as the complete fitress of the will to the moral law: 87 namely holiness is synonymous with what Kant describes in the Relicion as man's "rebirth" or "revolution in... man's disposition"(1.8. Ceslnnuna). ${ }^{88}$ Tfiat 1s, holiness consists in man's reversing his basic moral orientation from evil towards the good and adopting naxims out of pure respect for the moral law (1.e. man's becoming moreliy good). However, Kant represents this "revolution" as a possibility and even fact in "this life." And it is precisely because this revolution is realizable in man's mortal existence that there is a conflict between men's interior goodness (1.9. In the Cesinnung) and his actions. Thus, if the attainment of holiness means the achievement of moral goodness, then there is no reason to posit in immortal soul because men can evidently reverse his Gasinnung bofore

87 Ib10., p. 126.

88 Kent, Religion, p. 43 . 
death and thus become holy. The oniy thing that is not perfected 18 the correlation between Cesinnung and ections, which, causes men to see himself as progressing towards the good rather than already having atteined it. But, as we have seen, actions ars incidental to morality and therefore do not effect man's moral goodness or hollness. If men's ections did affect man's Gesinnung then one could see why holiness could only be attained in an after life in which men is free from the Iimitations of the sensuous nature. But, since the external actions of the sensuous nature are not influential or even relevant in the determination of moral goodness or holiness, then the retionale behind the immortelity of the soul is undermined. By separsting morallty from man's sensuous acts Kant seems to contradict one of his three fundemental, metaphysicel hypotheses: the immortality of the soul. However, the immortality of the soul is not cruclal for Kant's ethical system as a whole, and therefore the alleged contradiction betwean it and radical evil is serious but not fatal. We must now return to our discussion of the adequacy of Kant's understanding of radical avil.

The first thing that ought to be noted is the means by which Kant establishes the ract of "radical evil." Kant writes, "Thet such a corrupt propensity must indeed be rooted in man nead not be formally proved in view of the multitude of crying examples which experience... puts before our eyes." 89 In other words, the certainty of the existence of radicel evil is established by experience. However, eppeels to experience or history generally demonstrate nothing more then personal 
preference and are conclugive oniy ror those who are oredisposed towards accepting the very conclusion under consideration. That is, if ons is inclined to believe that there is "radical innate evil in human nature," then one will mogt likely see this belief confirmed in experience. If, on the other hand, one is not inclined towards such a belief, experience is brosd enough to afford persuasive "evidence" to deny the existence of such evil. Of course, experience could never establish a strictly logical connection between "radical evil" and human nature. Kant saw this and was content with the informality and Iimitations of such a proof," - . even If the existence of this propensity to evil in human nature can be demonstrated by experiential proofs of the real opposition, in time, of man's will to the law, such proofs do not teach us the essential character, of that propensity or the ground of this opposition." 90 But it is not clear that an appeal to experience can be regarded as forceful even if taken as the most informal of philosophical proofs for "radical innate evil in human nature." Naverthaless this is the only proof which Kant offers on behalf of a view of man which proposes to locete evil at the very core of man's personelity. If Kant had appealed to experience to verify the fact that men commit some moral misdeeds, then his proof would be more palatable. But Kant not only wished to establish this, but also that all men possess a fundamental propensity towards evil. It would seer that the establishment of this conclusion requires a much more stringent proof than the one Kant offers. 91

90 Ibid., pp. $30-31$.

91 It is, however, possible that the general religious climate of Kant's time would have made the appeal to experience more pawerful, both for Kant and his contamporaries, than it is for us today. 
The final point which we would like to make with respect to Kent's doctrine of radical evil ralates to its ultimate weakness. To sey that man is plagued by "radical innate suil in human neture" is to make very strang and far resching comment upon the nature of man. Indeed, the alleged contradiction between radical evil and moral freedom is almast obvious if we take Kant's descriotion of radical evil at "face value." However, as we exemine more closely the way in which kant defines the terms in his definition of radical ev1l, It becomes clear that what seemed to be a vary serious chargo against men's naturs, is in fact little more than the mere recognition that all men are immorel to limited extent. Kant writss, Mian (even the most wicked) doss not, under any maxim whatsoever, repudiate the moral law in the memner of a rebel (renouncing obedience to 1t)." 92 And yet, this is precisely whet many theologians and philosophers (e.g. St. Paul, Kirrkagard, Nietzsche, etc.) whe hoid to a view of men approximating radical evil would suggest: namely, that the radical nature of men's sin 1199 procisely in the fact that he does "repudiate the moral gaw in the manner of a rebel." Yet Kant felt it necessary to reject this possibllity becauso ho was, as we have already suggested, intensely awere of the possibility of violating his fundamental athical presupposition: human freedon. "Kant, like Pla to before him, expliclely considered the date which seemed contrary to his theory and, like plato, used his theory to dismiss the contravening ovidence es illusory. He gave his theory momentary support, but ha exposed its ultimate weakness." 93 The ultimate

$$
\begin{aligned}
& 92 \text { Kent, Religion, p. } 31 \text {. } \\
& 93 \text { Silber, "The Ethical Significance," p. cxxix. }
\end{aligned}
$$


weakness in Kant's understandirig op radierl ovil is, that for him ovil 18, in fact, neftige radical, innate or a part of humen nature in the common understanding of thess terms. Rather, Kantian radical evil seems to ropresent an aitempt on Kant's part to remain falthful to the religious tradition of his time. But, Kant's basic concern was never as much religious as it was ethical. And as it was clear to him that a strong definition of radical evil would indeed contradict moral autonomy, he qualified his definition in order to remove the contradiction. The result is a consistent view of moral autonomy and radicel evil, but one which does not do justice to a viow of man which could appropriately be described as "radical, Innete ovil in human nature."

Moral freedon, understood as the union of spontansity and autonony, and radical evil, understood es kent defines it, are in no way contradictory. Nevertinelass, the 1ssue of their compatibllity outglde of their Kantian definitions rematns an unanswered question. And the consistency of Kantian religion with Kantian ethics is not Iikely to be of great satisfaction to those who wish to take the notion of radical ovil as seriously and as literally as they do tho concept of morel. autonamy. 
SELECTED 8IBL IOGRAPHY

\section{PRIMARY SOUREES}

Kant, Immanuel. Erttloue of Practical Resson. Trans, with an intro. by Lewis whito Bock. New York: The Eobog-Merril Co., Inc., 1956.

Kant, Immanuel. Cejtinus of Pure Reason. Trans. by F. Max Muller. New York: Doubladay \& Company, Ine., 1966.

Kant, Immeriuel. Lecturgs on Ethics. Trans. by Louls Inifleld. New York: Hasper \& Row, Putlishers, 1963.

Kant, Immanuel. Raliolon Within the Limitg of Regson Along. Trans. by Theodore $M$. Greene and Hoyt $H$. Hudson. New York: Harper \& Row, Publishers, 1960.

Kant, Immanial. Ite Fundamanta] Principles of tha Metaphysic of Ethics. Trans. by 0tto Manthey-Zern. Now York: Appleton-Century-L̈rofts, Inc., 1938.

\section{SECONDARY SOURCES - Eagi:s}

Beck, Lewis whito. A Camentary on Kant's Critigue of Practice 1 Reason. Chicega: University of Chicago Press, 1960.

Calrd, Edward. The Eritical philesochy of Immanuel Kant. Naw York: Kraus Reprint Con, 1968.

Freeman, Donsld nig. Radical Evil and Original Sin: Kant's Doctrine of Freetom. (Orow University, Fh.D.) Ann Aroor, michigans University Mleroflims, Ine*, 1968.

Jones, W. T. Kent to Wittgengtein and Sartre. Now Yark Harcourt, Brece and world, Ine., 1960.

Jonea, W. T. Mnral Ity and Freodom in the philosoghy of Immanuel Kant. Dxford Univaratty Press, 1940 .

Karner, S. Kant. Seltimore, Maryland, Panguln Books, Iric., 1955.

Lahann, Faul L. Ethies In a Christian Context. New York: Herper \& Row Publishars, igs3.

Paton, H. J. Iha Ertsgorf 1 Imperative. Chicago: University of Chitago Press, 1948. 
Vaihinger, H. The Philogoghy of As If." Trans. by C. K. Ogden. New York: Hazcourt, Brace \& Company, Inc., 1924.

Wood, AIlen W. Kent's Mozal Rellalon. Ithaca, Naw York Cornell University Pregs., 1970.

\section{SECONDARY SOURCES - ArtIClES}

Greene, Theodore m. "The Historicel Context and Religinus Significance

of Kent's Relialon." Religion Within the Limits of Reason Alone

by Immanuel Kani. Trans. by Theodore M. Greene and Hoyt H. Hudson. New York: Harper \& Row, Publishers, 1960, pp. ix-ixxvili.

Sllber, John R. The Ethical Significance of Kant's Religion." Reliaion within the Limits of Reason Along by Immanuel Kant. Trans. by Theodors M. Greene and Hoyt H. Hudson. New York: Harper \& Row Publishers, 1960, pp. Ixxix-cxxxiv. 